\title{
Effectiveness of low-level laser therapy in patients with subacromial impingement syndrome: A randomized, placebo controlled, prospective study
}

\section{Subakromiyal sıkışma sendromu olan hastalarda düşük doz lazer tedavisinin etkinliği: Randomize, plasebo kontrollü, prospektif çalışma}

\author{
Pınar ATICI ÖZTÜRK ${ }^{1}$, Ilker ŞENGÜL ${ }^{2}$, Altınay Göksel KARATEPE ${ }^{2}$, Taciser KAYA ${ }^{2}$, Rezzan GÜNAYDIN ${ }^{3}$
}

${ }^{1}$ Kozaklı Fizik Tedavi ve Rehabilitasyon Hastanesi, Fiziksel Tip ve Rehabilitasyon Kliniği, Nevşehir

${ }^{2} \dot{I}_{z m i r}$ Bozyaka Ĕgitim ve Araştırma Hastanesi, Fiziksel Tip ve Rehabilitasyon Kliniği, İzmir

${ }^{3}$ Ordu Üniversitesi Tıp Fakültesi, Fiziksel Tip ve Rehabilitasyon Anabilim Dall, Ordu

\section{ABSTRACT}

Objective: To assess the effectiveness of low-level laser therapy [LLLT] in patients with subacromial impingement syndrome (SIS).

Methods: A total of 60 patients with SIS were randomly assigned into a laser or a placebo group. All participants also received 15 sessions of superficial heat treatment, transcutaneous electrical nerve stimulation therapy, and an exercise program. Outcomes were global pain severity, active and passive shoulder range of motion (ROM), and disability assessed by the Turkish Disabilities of the Arm, Shoulder and Hand (DASH-T) Outcome Measurement.

Results: There were statistically significant improvements in all outcome measurements in both groups. In comparison of both groups, median active and passive flexion, active and passive abduction, passive internal rotation, and passive external rotation scores were significantly higher in the laser group after the treatment $(p=0.015, P=0.004$, $\mathrm{p}=0.048, \mathrm{p}=0.014, \mathrm{p}=0.031$, and $\mathrm{p}=0.044$, respectively), but median differences in both groups were similar $(P>0.05)$. The median differences for global visual analogue scale pain and DASH-T scores, in both groups were also similar $(\mathrm{P}>0.05)$.

Conclusion: The results of our study demonstrated that both treatments provided improvement in pain, ROM, and disability status, but LLLT did not provide additional improvements.

Key words: Subacromial impingement syndrome, low-level laser therapy, shoulder disability

\section{ÖZET}

Amaç: Subakromiyal sıkışma sendromu (SSS) olan hastalarda düşük doz lazer tedavisinin (DDLT) etkinliğini değerlendirmek.

Yöntemler: SSS olan toplam 60 hasta lazer ve plasebo lazer gruplarına randomize edildi. Tüm katılımcılar aynı zamanda 15 seans boyunca yüzeyel sıcak uygulama, transkutanöz elektriksel sinir stimülasyon (TENS) tedavisi ve bir egzersiz programı aldı. Sonuç ölçümleri global ağrı şiddeti, aktif ve pasif omuz hareket açıklı̆̆ı (EHA) ve Kol, Omuz ve El Sorunları Anketi [(Turkish Disabilities of the Arm, Shoulder and Hand Outcome Measurement (DASH-T)] idi.

Bulgular: Her iki grupta da tüm sonuç ölçümlerinde istatistiksel olarak anlamlı düzelme vardı. Tedavi sonrasında iki grubun karşılaştırılmasında ortanca aktif ve pasif fleksiyon, aktif ve pasif abduksiyon, pasif iç rotasyon ve pasif dıs rotasyon lazer grubunda anlamlı olarak daha yüksekken (sırasıyla $p=0.015, p=0.004, p=0.048, p=0.031$ ve $p=0.044)$, farkların ortancası iki grup arasında benzerdi $(p>0.05)$. Yine VAS ağrı farklarının ortancası ve DASH-T farklarının ortancası iki grupta benzerdi $(p>0.05)$.

Sonuç: Çalışmamızın sonuçları her iki tedavinin de ağrı, EHA ve yetersizlik durumunda iyileşme sağladığını, ancak DDLT'nin ilave iyileşmeye katkısının olmadığını gösterdi.

Anahtar kelimeler: Subakromiyal sıkışma sendromu, düşük doz lazer tedavisi, omuz yetersizliği

Alındığı tarih: 21.05.2015

Kabul tarihi: 06.07.2015

Yazışma adresi: Uzm. Dr. İlker Şengül, Saim Çıkrıkçı Cad. No:59, Bozyaka-Karabağlar-İzmir e-mail: ilkrsngl@gmail.com 


\section{INTRODUCTION}

Shoulder pain is one of the major pain syndromes in the musculoskeletal system that adversely affects the daily activities of life. The incidence is higher in women and in people aged over 45 years ${ }^{(1)}$. The most frequent cause of shoulder pain is subacromial impingement syndrome (SIS) ${ }^{(2)}$ which is caused by compression of the rotator cuff, long head of the biceps tendon, and subacromial bursa between the humerus and coracoacromial arch as a result of an intrinsic or an extrinsic mechanism ${ }^{(3)}$.

Treatment of SIS is primarily conservative, including analgesic and anti-inflammatory drugs, corticosteroid injections, and occupational and physiotherapy interventions ${ }^{(4)}$. Of the physical therapy interventions, low-level laser therapy (LLLT) is a relatively new physical therapy modality that is supposed to reduce pain, accelerate wound healing, and have a ameliorating effect on the inflammatory process ${ }^{(5)}$.

There are conflicting results regarding the effectiveness of LLLT in patients with SIS ${ }^{(6)}$. The parameters specific to co-interventions with laser, and lack of diagnosis or classification criteria for SIS might have altered the results. Therefore, we conducted a new, prospective, randomized, single-blind study to assess the effectiveness of LLLT in patients with SIS.

\section{MATERIAL and METHODS}

This study was a randomized, placebo controlled, single-blind trial. The patients were randomly assigned into 2 groups: a laser group and a placebo laser group. Randomization was allocated by the permuted block randomization method.

A total of 60 patients with SIS who were 18 to 75 years old were included in the study. Diagnosis of SIS was based on clinical presentation, detailed physical and neurological examination, and magnetic resonance imaging (MRI) findings. The exclusion criteria were the presence of only bicipital tendinitis, drop arm test positivity, neurological impairments, systemic inflammatory rheumatic diseases, bacterial, viral, or fungal infections, malign diseases, decompensated heart failure and presence of a cardiac pacemaker, angina, advanced asthma, calcific tendinitis, and tears of rotator cuff tendons detected by MRI. A history of physical therapy, surgery of neck and shoulder region, and subacromial or intra-articular glucocorticoid injection within 1 year were also included in the exclusion criteria.

In the laser group, LLLT was applied with a dosage of 4 joules (total of 12 joules) for 40 seconds (total of 120 seconds) to each of 3 points (subacromial space, supraspinatus tendon insertion, and glenohumeral joint) 5 times a week for 3 weeks. A gallium-aluminum-arsenide (GaAlAs, infrared laser) diode laser device (Chattanooga Group, USA) with a wavelength of $850 \mathrm{~nm}$, power output of $100 \mathrm{~mW}$, continuous wave, and $0.07-\mathrm{cm}^{2}$ spot area was used for the laser therapy. The placebo laser was applied in the same way; although the device was turned on active, no laser irradiation was applied. The patients and the operator used protective eyeglasses during therapy for safety. In addition to laser or placebo laser therapy, both groups received superficial heat treatment (hot pack) for 10 minutes, transcutaneous electrical nerve stimulation (TENS) therapy for $20 \mathrm{~min}$ utes, and an exercise program. TENS was delivered via 2 electrodes with a frequency of $100 \mathrm{~Hz}$, pulse duration of 200 microseconds, and tolerated dose intensity. The exercise program included range of motion (ROM) exercises as well as stretching and strengthening exercises. Each exercise session was performed once a day with 15 repetitions in a supervised manner. The therapy program was applied 5 times a week for 3 weeks (total of 15 sessions).

Outcome measures were pain severity, shoulder ROM, and disability status. Global pain severity was assessed by visual analogue scale (VAS) which ranged from no pain (0-mm mark) to severe pain 100-mm mark). ROMs of flexion, extension, abduction, internal rotation, and external rotation were measured actively and passively by using a goniometer. All motions were measured with the patients in the supine position except for extension, which was 
measured in the prone position. Disability status was evaluated by using the Turkish Disabilities of the Arm, Shoulder and Hand (DASH-T) Outcome Measurement questionnaire consisted of 2 parts which contained the disability/symptom questions (30 items) and the optional high-performance sport/ music or work section (4 items). We scored the disability/symptom questions (30 items, scored 1-5). The responses were summed and averaged. This value was then used in an equation to find a score out of 100. A higher score indicated greater disability ${ }^{(7)}$.

The study was conducted in concordance with the principles of the Helsinki Declaration and approved by the Institutional Academic Board. All patients gave written informed consent before randomization.

IBM SPSS 21.0 statistical software package was used for analysis. Nonparametric tests were used because of the non-Gaussian distribution of the variables. Mann-Whitney U test for independent samples was used to compare the groups. Wilcoxon signed-

Table 1. Demographic and clinical characteristics of the patients in both groups.

\begin{tabular}{lccc}
\hline & $\begin{array}{c}\text { Laser } \\
{[\mathbf{N = 3 0}]}\end{array}$ & $\begin{array}{c}\text { Placebo laser } \\
{[\mathbf{N}=\mathbf{3 0}]}\end{array}$ & P-value \\
\hline Age, years [mean $\pm \mathrm{SD}]$ & $51.3 \pm 8.7$ & $54.5 \pm 7.2$ & $0.124^{\mathrm{a}}$ \\
Gender, N [F/M] & $22 / 8$ & $23 / 7$ & $0.766^{\mathrm{b}}$ \\
Dominant extremity, N [R/L] & $25 / 5$ & $29 / 1$ & $0.195^{\mathrm{b}}$ \\
Affected shoulder side, N [R/L] & $15 / 15$ & $22 / 8$ & $0.063^{\mathrm{b}}$ \\
Symptom duration, month [med & $5.5(1,72)$ & $8(2,60)$ & $0.024^{\mathrm{c}}$ \\
(min, max)] & & & \\
\end{tabular}

$S D=$ standard deviation, $F=$ female, $M=$ male, $R=$ right,$L=$ left , med $=$ median, min $=$ minimum, max $=$ maximum

${ }^{a}$ as determined by independent 2 -sample $t$ test, ${ }^{b}$ as determined by chisquare test, ${ }^{c}$ as determined by Mann-Whitney U test

Table 2. Baseline and posttreatment measurements of ROM, VAS, and DASH-T.

\begin{tabular}{|c|c|c|c|c|}
\hline & Group & Pretreatment & Posttreatment & $\mathbf{P}^{\mathbf{a}}$ \\
\hline \multicolumn{5}{|l|}{ ROM [med (min, max)] } \\
\hline \multirow[t]{3}{*}{ Abduction [active] } & Laser & $120[90,180]$ & $180[120,180]$ & $<0.001$ \\
\hline & Placebo laser & $105[40,180]$ & $180[80,180]$ & $<0.001$ \\
\hline & $\mathrm{P}^{\mathrm{b}}$ & 0.235 & 0.015 & \\
\hline \multirow{3}{*}{ Abduction [passive] } & Laser & $130[95,180]$ & $180[130,180]$ & $<0.001$ \\
\hline & Placebo laser & $125[80,180]$ & $180[90,180]$ & $<0.001$ \\
\hline & $\mathrm{P}^{\mathrm{b}}$ & 0.301 & 0.004 & \\
\hline \multirow[t]{3}{*}{ Flexion [active] } & Laser & $120[80,180]$ & $180[130,180]$ & $<0.001$ \\
\hline & Placebo laser & $120[60,180]$ & $170[90,180]$ & $<0.001$ \\
\hline & $\mathrm{P}^{\mathrm{b}}$ & 0.467 & 0.048 & \\
\hline \multirow[t]{3}{*}{ Flexion [passive] } & Laser & $130[90,180]$ & $180[140,180]$ & $<0.001$ \\
\hline & Placebo laser & $130[90,180]$ & $180[100,180]$ & $<0.001$ \\
\hline & $\mathrm{P}^{\mathrm{b}}$ & 0.700 & 0.014 & \\
\hline \multirow[t]{3}{*}{ Extension [active] } & Laser & $40[20,60]$ & $60[40,60]$ & $<0.001$ \\
\hline & Placebo laser & $40[15,60]$ & $60[30,60]$ & $<0.001$ \\
\hline & $\mathrm{P}^{\mathrm{b}}$ & 0.976 & 0.116 & \\
\hline \multirow[t]{3}{*}{ Extension [passive] } & Laser & $50[25,60]$ & $60[50,60]$ & $<0.001$ \\
\hline & Placebo laser & $50[20,60]$ & $60[50,60]$ & $<0.001$ \\
\hline & $\mathrm{P}^{\mathrm{b}}$ & 0.973 & 0.254 & \\
\hline \multirow[t]{3}{*}{ Internal rotation [active] } & Laser & $40[20,80]$ & $77.5[40,90]$ & $<0.001$ \\
\hline & Placebo laser & $40[20,80]$ & $65[35,90]$ & $<0.001$ \\
\hline & $\mathrm{P}^{\mathrm{b}}$ & 0.472 & 0.151 & \\
\hline \multirow[t]{3}{*}{ Internal rotation [passive] } & Laser & $50[30,80]$ & $80[50,90]$ & $<0.001$ \\
\hline & Placebo laser & $47.5[30,80]$ & $72.5[40,90]$ & $<0.001$ \\
\hline & $\mathrm{P}^{\mathrm{b}}$ & 0.653 & 0.031 & \\
\hline \multirow[t]{3}{*}{ External rotation [active] } & Laser & $47.5[30,90]$ & $90[50,90]$ & $<0.001$ \\
\hline & Placebo laser & $50[20,90]$ & $77.5[45,90]$ & $<0.001$ \\
\hline & $\mathrm{P}^{\mathrm{b}}$ & 0.893 & 0.089 & \\
\hline \multirow[t]{3}{*}{ External rotation [passive] } & Laser & $52.5[35,90]$ & $90[60,90]$ & $<0.001$ \\
\hline & Placebo laser & $60[30,90]$ & $85[50,90]$ & $<0.001$ \\
\hline & $\mathrm{P}^{\mathrm{b}}$ & 0.887 & 0.044 & \\
\hline \multirow[t]{3}{*}{ VAS [med (min, max)] } & Laser & $77.5[39,91]$ & $39.5[13,74]$ & $<0.001$ \\
\hline & Placebo laser & $78[47,100]$ & $41.5[10,84]$ & $<0.001$ \\
\hline & $\mathrm{P}^{\mathrm{b}}$ & 0.351 & 0.169 & \\
\hline \multirow[t]{3}{*}{ DASH-T [med (min, max)] } & Laser & $64.1[17.5,81.7]$ & $28.8[4.2,60.7]$ & $<0.001$ \\
\hline & Placebo laser & $67.7[25,86.7]$ & $35.4[15,75]$ & $<0.001$ \\
\hline & $\mathrm{P}^{\mathrm{b}}$ & 0.403 & 0.120 & \\
\hline
\end{tabular}

ROM = range of motion; VAS = visual analogue scale; DASH-T = Turkish Disabilities of the Arm, Shoulder and Hand Outcome Measurement; med = median $;$ min = minimum; max = maximum, $a$ as determined by Wilcoxon signed-rank test,$b$ as determined by the Mann-Whitney $U$ test 
Table 3. Median differences of ROM, pain severity, and DASH-T assessments between baseline and posttreatment.

\begin{tabular}{lccc}
\hline & Laser & Placebo laser & P-value $^{\mathbf{a}}$ \\
\hline ROM [med (min, max)] & & & \\
Active flexion & $45(0,90)$ & $40(0,90)$ & 0.479 \\
Passive flexion & $40(0,80)$ & $30(0,90)$ & 0.268 \\
Active abduction & $50(0,90)$ & $40(0,80)$ & 0.293 \\
Passive abduction & $50(0,80)$ & $40(0,75)$ & 0.264 \\
Active internal rotation & $25(0,60)$ & $20(0,60)$ & 0.277 \\
Passive internal rotation & $20(0,50)$ & $17.5(0,50)$ & 0.150 \\
Active external rotation & $30(0,0)$ & $22.5(0,50)$ & 0.078 \\
Passive external rotation & $30(0,50)$ & $20(0,45)$ & 0.057 \\
VAS [med (min, max)] & $-35[8,66]$ & $-35.5[11,52]$ & 0.929 \\
DASH-T [med (min, max)] & $-32.4[5,58.25]$ & $-27.75[10,50]$ & 0.673 \\
& & & \\
\hline
\end{tabular}

ROM = range of motion; DASH-T = Turkish Disabilities of the Arm, Shoulder and Hand Outcome Measurement; med = median; min = minimum; max = maximum; VAS = visual analogue scale, a as determined by Mann-Whitney $U$ test

rank test was used to study changes during treatment within both groups. Chi-square tests or Fisher's exact test for independent samples were used to compare the groups for categorical variables. A p-value of $<0.05$ was taken into consideration to indicate significance.

\section{RESULTS}

All the participants in both groups completed the therapy program. The mean age of the study population was $52.9 \pm 8.1$ years. There were no statistically significant differences between the groups as for the patient characteristics except for disease duration. The symptom duration was significantly higher in the placebo laser group than in the laser group (Table 1).

There were statistically significant improvements in pain severity, shoulder ROM, and DASH-T in both groups after treatment. ROM measurements of active flexion, active abduction, passive internal rotation, and external rotation were significantly higher in the laser group than in the placebo laser group after the treatment (Table 2). The median intergroup differences for all measurements were similar (Table 3).

In the placebo laser, and laser groups $86.7 \%$, and $90 \%$ of the patients were satisfied with the therapy. None of the participants reported any adverse reactions or side effects.

\section{DISCUSSION}

The results of our study demonstrated that both LLLT and placebo LLLT provided improvements in pain, ROM, and disability status, but LLLT did not provide additional improvements.

The pain-relieving effect of LLLT was previously considered to be related to its anti-inflammatory effects ${ }^{(8)}$. LLLT can modulate inflammatory pain by reducing levels of biochemical markers, neutrophil cell influx, oxidative stress, and the formation of edema in a dosedependent manner. The other mechanisms suggested concerning the pain-relieving effect of LLLT are altering excitation and nerve conduction in peripheral nerves and stimulation the release of endogenous endorphins ${ }^{(9)}$. LLLT may accelerate collateral circulation and enhance microcirculation so as to normalize the functional features of the injured areas ${ }^{(10)}$. LLLT may also reduce histological abnormalities, collagen concentration, and oxidative stress ${ }^{(11)}$. LLLT is suggested to be able to accelerate the healing process of tendinous tissue after an injury, increasing fibroblast cell proliferation and collagen synthesis ${ }^{(12)}$.

The clinical effectiveness of LLLT is debatable because of the lack of consensus about the dosage to be used ${ }^{(8,13)}$, delivery system, and the wavelength to be delivered. There are numerous LLLT methods in the literature. World Association of Laser Therapy (WALT) published recommended treatment doses for LLLT $^{(14)}$. According to this recommendation for 780to $860-\mathrm{nm}$ GaAlAs laser devices with a mean output of 5 to $500 \mathrm{~mW}$, irradiation times should range between 20 and 300 seconds and should cover most of the pathological tissue in the tendon/synovia for supraspinatus tendinopathies. The irradiation should be applied at 2 to 3 points or square centimeters and the optimal dose should be 8 joules (minimum 4 joules per point). The therapeutic dose window typically ranges from $+/-50 \%$ of given values. We used a GaAlAs diode laser device with a wavelength of $850 \mathrm{~nm}$ and an output of $100 \mathrm{~mW}$. The LLLT dosage was 4 joules (total of 12 joules) at each point for 40 seconds (total of 120 seconds) applied with a con- 
tinuous wave. It was within the therapeutic dose window according to the recommended dose.

Some trials have assessed the effect of laser therapy, yet the results of these trials are conflicting. England et al. ${ }^{(15)}$ studied infrared laser therapy (904 nm, 3 times weekly for 2 weeks) in 30 patients with supraspinatus or bicipital tendinitis. They compared the laser therapy with a dummy laser and drug treatment and reported that laser therapy was effective in tendinitis of the shoulder. Vecchio et al. ${ }^{(16)}$ compared LLLT (830-nm GaAlAs diode laser) with a dummy laser twice weekly for 8 weeks in patients with rotator cuff tendinitis. The result of their trial failed to demonstrate the effectiveness of laser therapy. In another study, Saunders ${ }^{(17)}$ used LLLT (820 nm, 40 $\mathrm{mW}$ output, $5000 \mathrm{~Hz}$, dose of $30 \mathrm{~J} / \mathrm{cm}^{2}$ ) in patients with supraspinatus tendinitis. In her trial, LLLT was superior to the dummy laser, but the trial was limited by small numbers. Bingöl et al. ${ }^{(18)}$ compared LLLT (904 nm, $2000 \mathrm{~Hz}, \mathrm{GaAs}$ diode laser) with a placebo laser in 40 patients with shoulder pain. All participants were also given the same exercise protocol. Although there was a significant posttreatment improvement within both groups, there was no significant improvement in pain, active shoulder ROM, or algometric sensitivity in the laser-treatment group compared with the control group.

Regarding SIS, some trials were conducted with different wavelengths and dosages. Of these trials, Yeldan et al. ${ }^{(19)}$ studied GaAs LLLT (904 nm, 2000 $\mathrm{Hz}$ ) in patients with SIS. They randomized 67 patients with SIS into 2 groups: a laser group and a placebo laser group. All participants were also given superficial cold treatment and a progressive exercise program including ROM as well as strengthening and stretching exercises in a supervised manner for 15 sessions. Both groups showed significant improvements; however, there were no significant intergroup differences regarding pain, functional assessment, and disability after the treatment . Bal et al. ${ }^{(20)}$ compared LLLT (904 nm, $5500 \mathrm{~Hz}, \mathrm{GaAs}$ diode laser) and a home exercise program with a home exercise program alone. The exercise program included a pendulum exercise, a passive shoulder self-stretching exercise, isometrics, elastic band (Thera-Band ${ }^{\circledR}$ ) exercises, strengthening exercises for scapular stabilizers, and advanced muscle strengthening exercises with dumbbells in a progressive manner. LLLT was applied for 10 sessions, and the exercise program lasted for 12 weeks in both groups. The results of their study failed to demonstrate any distinct advantage of LLLT over exercise alone. In another study, in which the laser device had the same specifications as ours $(850 \mathrm{~nm}$, power output of 100 $\mathrm{mW}$, continuous wave, $0.07-\mathrm{cm}^{2}$ spot area, GaAlAs infrared laser), Dogan et al. ${ }^{(21)}$ reported that LLLT was not superior to placebo laser therapy. They randomized 52 patients with SIS into 2 groups: a laser group and a placebo laser group. In addition to laser or placebo laser therapy, all participants were given a cold pack and an exercise program for 14 sessions. However, there were significant improvements in pain severity, ROM, and disability within both groups, and there were no significant differences between the groups. Calis et al. ${ }^{(22)}$ compared therapeutic ultrasound [with a hot pack and exercise], laser treatment (904 nm, $6 \mathrm{~mW}$ average power, $1 \mathrm{~J} / \mathrm{cm}^{2}$ dosage, $16 \mathrm{~Hz}$, for 2 minutes) (also with a hot pack and exercise), and exercise (with a hot pack) in patients with SIS. The results of their trial showed that all 3 treatment regimens were effective, but none were superior. In all these studies conducted for SIS, LLLT was not superior to other interventions. In contrast to these studies, Abrisham et al. (23) reported that LLLT combined with exercise was more effective than exercise therapy alone in pain relief and increased shoulder ROM. In a systematic review, Green et al. ${ }^{(24)}$ indicated that exercise therapy was effective in recovery from rotator cuff disease, but laser therapy was not effective for rotator cuff tendinitis. In our study, besides active or placebo laser therapy, all the patients received a physical therapy program including a hot pack, TENS, and exercises. In both groups, significant improvement was achieved with therapies. Therapeutic exercise is an effective intervention in reducing pain and improving the functional status in patients with SIS ${ }^{(25,26)}$. Because of the additive effect of co-interventions, an isolated effect of 
LLLT might have not been elucidated. Michener et al. (6) pointed out that laser therapy was effective only when used in isolation and not when combined with exercise. Laser therapy as a single intervention was recommended in patients who were unable to perform therapeutic exercises.

Some limitations to our study included our diagnostic method of SIS, a small sample number, shorter follow-up period, and the subjective pain assessment being limited to VAS in a global perspective which was not performed during movement or night. VAS scores for movement were better indicators than VAS scores at rest for comparison of the effect of different treatmentoptions ${ }^{(13)}$.Also, durations of patients' disease were significantly different between groups, which might have affected the results.

In conclusion, the results of this study demonstrated that LLLT is not superior to placebo in the treatment of SIS. Although a majority of studies, including ours, have shown that LLLT is not an effective treatment option in the management of SIS, LLLT should be used in patients with SIS who are not in the habit of exercising or who cannot perform exercises. There is also a need for more LLLT trials with optimal dosage, duration, and wavelength to demonstrate whether LLLT is effective in patients with SIS.

\section{REFERENCES}

1. Greving K, Dorrestijn O, Winters JC, Groenhof F, van der Meer K, Stevens M, et al. Incidence, prevalence, and consultation rates of shoulder complaints in general practice. Scand $J$ Rheumatol 2012;41:150-5. http://dx.doi.org/10.3109/03009742.2011.605390

2. Faber E, Kuiper JI, Burdorf A, Miedema HS, Verhaar JA. Treatment of impingement syndrome: A systematic review of the effects on functional limitations and return to work. $J$ Occup Rehabil 2006;16:7-25. http://dx.doi.org/10.1007/s 10926-005-9003-2

3. Michener LA, McClure PW, Karduna AR. Anatomical and biomechanical mechanisms of subacromial impingement syndrome. Clin Biomech (Bristol, Avon) 2003;18:369-79. http://dx.doi.org/10.1016/S0268-0033(03)00047-0

4. Diercks R, Bron C, Dorrestijn O, Meskers C, Naber R, de Ruiter T, et al. Guideline for diagnosis and treatment of subacromial pain syndrome. Acta Orthop 2014;85:314-22. http://dx.doi.org/10.3109/17453674.2014.920991. Epub 2014 May 21.

5. Kreisler M, Christoffers AB, Willershausen B, d'Hoedt B. Effect of low-level GaAlAs laser irradiation on the prolifera- tion rate of human periodontal ligament fibroblasts: An in vitro study. J Clin Periodontol 2003;30:353-8. http://dx.doi.org/10.1034/j.1600-051X.2003.00001.x

6. Michener LA, Walsworth MK, Burnet EN. Effectiveness of rehabilitation for patients with subacromial impingement syndrome: A systematic review. J Hand Ther 2004;17:152-64. http://dx.doi.org/10.1197/j.jht.2004.02.004

7. The DASH Outcome Measure: Disabilities of the Arm, Shoulder and Hand. Available translations. Retrieved July 15, 2014, from: www.dash.iwh.on.ca/available-translations.

8. Bjordal JM, Couppé C, Chow RT, Tunér J, Ljunggren EA. A systematic review of low level laser therapy with locationspecific doses for pain from chronic joint disorders. Aust $J$ Physiother 2003;49:107-16. http://dx.doi.org/10.1016/S0004-9514(14)60127-6

9. Bjordal JM, Johnson MI, Iversen V, Aimbire F, LopesMartins RA. Low-level laser therapy in acute pain: A systematic review of possible mechanisms of action and clinical effects in randomized placebo-controlled trials. Photomed Laser Surg 2006;24:158-68. http://dx.doi.org/10.1089/pho.2006.24.158

10. Ihsan FR. Low-level laser therapy accelerates collateral circulation and enhances microcirculation. Photomed Laser Surg 2005;23:289-94. http://dx.doi.org/10.1089/pho.2005.23.289

11. Fillipin LI, Mauriz JL, Vedovelli K, Moreira AJ, Zettler CG, Lech O, et al. Low-level laser therapy (LLLT) prevents oxidative stress and reduces fibrosis in rat traumatized Achilles tendon. Lasers Surg Med 2005;37:293-300. http://dx.doi.org/10.1002/lsm.20225

12. Carrinho PM, Renno AC, Koeke P, Salate AC, Parizotto NA, Vidal BC. Comparative study using $685-\mathrm{nm}$ and $830-\mathrm{nm}$ lasers in the tissue repair of tenotomized tendons in the mouse. Photomed Laser Surg 2006;24:754-8. http://dx.doi.org/10.1089/pho.2006.24.754

13. Montes-Molina R, Martínez-Rodríguez ME, Rodríguez AB, Martínez-Ruiz F, Prieto-Baquero A. Interferential light therapy in the treatment of shoulder tendinopathies: A randomized controlled pilot study. Clin Rehabil 2012;26:1114-22 . http://dx.doi.org/10.1177/0269215512445068

14. WALT: Recommended treatment doses for low level laser therapy. Retrieved July 14, 2014, from: http://waltza.co.za/ documentation links/recommendations/dosage-recommendations.

15. England S, Farrell AJ, Coppock JS, Struthers G, Bacon PA. Low power laser therapy of shoulder tendonitis. Scand $J$ Rheumatol 1989;18:427-31. http://dx.doi.org/10.3109/03009748909102106

16. Vecchio P, Cave M, King V, Adebajo AO, Smith M, Hazleman BL. A double-blind study of the effectiveness of low level laser treatment of rotator cuff tendinitis. $\mathrm{Br} \mathrm{J}$ Rheumatol 1993;32:740-2. http://dx.doi.org/10.1093/rheumatology/32.8.740

17. Saunders L. The efficacy of low-level laser therapy in supraspinatus tendinitis. Clin Rehabil 1995;9:126-34. http://dx.doi.org/10.1177/026921559500900207

18. Bingöl U, Altan L, Yurtkuran M. Low-power laser treatment for shoulder pain. Photomed Laser Surg 2005;23:459-64. http://dx.doi.org/10.1089/pho.2005.23.459

19. Yeldan I, Cetin E, Ozdincler AR. The effectiveness of lowlevel laser therapy on shoulder function in subacromial impingement syndrome. Disabil Rehabil 2009;31:935-40. http://dx.doi.org/10.1080/09638280802377985

20. Bal A, Eksioglu E, Gurcay E, Gulec B, Karaahmet O, Cakci 
A. Low-level laser therapy in subacromial impingement syndrome. Photomed Laser Surg 2009;27:31-6.

http://dx.doi.org/10.1089/pho.2007.2222

21. Dogan SK, Ay S, Evcik D. The effectiveness of low laser therapy in subacromial impingement syndrome: A randomized placebo controlled double-blind prospective study. Clinics (Sao Paulo) 2010;65:1019-22.

http://dx.doi.org/10.1590/S1807-59322010001000016

22. Calis HT, Berberoglu N, Calis M. Are ultrasound, laser and exercise superior to each other in the treatment of subacromial impingement syndrome? A randomized clinical trial. Eur J Phys Rehabil Med 2011;47:375-80.

23. Abrisham SM, Kermani-Alghoraishi M, Ghahramani R, Jabbari L, Jomeh H, Zare M. Additive effects of low-level laser therapy with exercise on subacromial syndrome: A randomised, double-blind, controlled trial. Clin Rheumatol
2011;30:1341-6.

http://dx.doi.org/10.1007/s10067-011-1757-7

24. Green S, Buchbinder R, Hetrick S. Physiotherapy interventions for shoulder pain. Cochrane Database Syst Rev 2: CD004258, 2003. http://dx.doi.org/10.1002/14651858.cd004258

25. Ludewig PM, Borstad JD. Effects of a home exercise programme on shoulder pain and functional status in construction workers. Occup Environ Med 2003;60:841-9. http://dx.doi.org/10.1136/oem.60.11.841

26. Kuhn JE. Exercise in the treatment of rotator cuff impingement: A systematic review and a synthesized evidence-based rehabilitation protocol. J Shoulder Elbow Surg 2009;18:13860 .

http://dx.doi.org/10.1016/j.jse.2008.06.004 